\title{
New Coleoptera records from New Brunswick, Canada: Histeridae
}

\author{
Reginald P. Webster', Scott Makepeace², Ian DeMerchant', Jon D. Sweeney' \\ I Natural Resources Canada, Canadian Forest Service - Atlantic Forestry Centre, 1350 Regent St., P.O. Box \\ 4000, Fredericton, NB, Canada E3B 5P7 2 Habitat Program, Fish and Wildlife Branch, New Brunswick \\ Department of Natural Resources, P.O. Box 6000, Fredericton, NB, Canada E3B $5 \mathrm{HI}$
}

Corresponding author: Reginald P. Webster (reginaldwebster@rogers.com)

Academic editor:J. Klimaszewski | Received 5 December 2011 | Accepted 22 December 2011 | Published 4 April 2012

Citation: Webster RP, Makepeace S, DeMerchant I, Sweeney JD (2012) New Coleoptera records from New Brunswick, Canada: Histeridae. In: Anderson R, Klimaszewski J (Eds) Biodiversity and Ecology of the Coleoptera of New Brunswick, Canada. ZooKeys 179: 11-26. doi: 10.3897/zookeys.179.2493

\begin{abstract}
Eighteen species of Histeridae are newly reported from New Brunswick, Canada. This brings the total number of species known from New Brunswick to 42. Seven of these species, Acritus exguus (Erichson), Euspilotus rossi (Wenzel), Hypocaccus fitchi (Marseul), Dendrophilus kiteleyi Bousquet and Laplante, Platysoma cylindricum (Paykull), Atholus sedecimstriatus (Say), and Margarinotus harrisii (Kirby) are recorded from the Maritime provinces for the first time. Collection and bionomic data are presented for these species.
\end{abstract}

\section{Keywords}

Histeridae, new records, Canada, New Brunswick

\section{Introduction}

Bousquet and Laplante (2006) reviewed the Histeridae of Canada. Histeridae live in dung, carcasses, decaying vegetable matter, under bark, and in nests of mammals, birds, and ants (Bousquet and Laplante 2006). Most species are predaceous. Species living in decaying organic matter feed mainly on Diptera larvae, whereas those living under bark feed on eggs, larvae, and pupae of wood-boring beetles, and thus, members 
of this family are important ecologically (Bousquet and Laplante 2006). However, the biology of most of the Histeridae occurring in North America is still poorly known.

Bousquet and Laplante (2006) reported 135 species of Histeridae from Canada and 22 species from New Brunswick. Majka (2008) added another two species in his review of the Atlantic Canadian Histeridae. Here, we report another 18 species, bringing the total number of species known from the province to 42 .

\section{Methods and conventions}

The following records are based in part on specimens collected as part of a general survey by the first author to document the Coleoptera fauna of New Brunswick, a study to document the Coleoptera fauna of barred owl (Strix varia Barton) nests, and specimens obtained as by-catch in Lindgren 12-funnel traps (ConTech Inc., Delta, BC) during a study to develop a general attractant for the detection of invasive species of Cerambycidae.

\section{Collection methods}

A variety of collection methods were employed to collect the specimens reported in this study. General details are outlined in Webster et al. (2009, Appendix). See Webster et al. (in press) for details of the methods used for deployment of Lindgren traps and sample collection. A significant number of Histeridae were collected from the nest contents of barred owls, which usually nest several meters or more above ground in tree cavities or in artificial nest boxes. Trees were climbed, and the entire nest contents (usually about 2-3 L) were removed (usually when chicks were present or shortly after the chicks had left the nest). Nest contents were replaced with wood chips similar to those normally used in nest boxes. Contents were hand sifted, and all beetles were removed from the samples. A detailed description of the habitat was recorded for all specimens collected during the Coleoptera survey. Locality and habitat data are presented exactly as recorded on labels for each specimen. This information, as well as additional collecting notes, is summarized and discussed in the collection and habitat data for each species.

\section{Distribution}

Distribution maps, created using ArcMap and ArcGIS, are presented for each species from New Brunswick. Every species is cited with current distribution in Canada and Alaska, using abbreviations for the state, provinces, and territories. New provincial records are indicated in bold under Distribution in Canada and Alaska. The following abbreviations are used in the text: 


\begin{tabular}{ll|ll}
\hline AK & Alaska & MB & Manitoba \\
\hline YT & Yukon Territory & ON & Ontario \\
\hline NT & Northwest Territories & QC & Quebec \\
\hline NU & Nunavut & NB & New Brunswick \\
\hline BC & British Columbia & PE & Prince Edward Island \\
\hline AB & Alberta & NS & Nova Scotia \\
\hline SK & Saskatchewan & NF \& LB & Newfoundland and Labrador \\
\hline
\end{tabular}

Acronyms of collections examined and referred to in this study are as follows:

AFC Atlantic Forestry Centre, Natural Resources Canada, Canadian Forest Service, Fredericton, New Brunswick, Canada

CNC Canadian National Collection of Insects, Arachnids and Nematodes, Ottawa, Ontario, Canada

NBM New Brunswick Museum, Saint John, New Brunswick, Canada

RWC Reginald P. Webster Collection, Charters Settlement, New Brunswick, Canada

\section{Results}

Eighteen species of Histeridae are newly reported from New Brunswick, bringing the total number of species known from the province to 42 (Table 1.). Seven species, Acritus exguus (Erichson), Euspilotus rossi (Wenzel), Hypocaccus fitchi (Marseul), Dendrophilus kiteleyi Bousquet and Laplante, Platysoma cylindricum (Paykull), Atholus sedecimstriatus (Say), and Margarinotus harrisii (Kirby) are newly recorded for the Maritime provinces of Canada.

Table I. Species of Histeridae known from New Brunswick, Canada

\begin{tabular}{l}
\hline Subfamily Abraeinae MacLeay \\
\hline Tribe Plegaderinae Portevin \\
\hline Plegaderus confusus Bousquet \& Laplante \\
\hline Plegaderus sayi Marseul \\
\hline Tribe Acritini Wenzel \\
\hline Acritus exiguus (Erichson)** \\
\hline Aeletes politus (LeConte) \\
\hline Subfamily Saprininae Blanchard \\
\hline Baeckmanniolus dimidiatipennis (LeConte) \\
\hline Euspilotus assimilis (Paykull) \\
\hline Euspilotus rossi (Wenzel)** \\
\hline Geomysaprinus moniliatus (Casey) \\
\hline Gnathoncus barbatus Bousquet \& Laplante* \\
\hline Gnathoncus communis (Marseul)* \\
\hline Gnathoncus rotundatus (Kugelann) \\
\hline Hypocaccus bigener (LeConte) \\
\hline Hypocaccus fitchi (Marseul)** \\
\hline Hypocaccus fraternus (Say)
\end{tabular}

\begin{tabular}{l}
\hline Subfamily Dendrophilinae Reitter \\
\hline Tribe Dendrophilini Reitter \\
\hline Dendrophilus kiteleyi Bousquet \& Laplante** \\
\hline Dendrophilus punctatus (Herbst)* \\
\hline Tribe Paromalini Reitter \\
\hline Carcinops pumilo (Erichson) \\
\hline Paromalus teres LeConte \\
\hline Subfamily Histerinae Gyllenhal \\
\hline Tribe Platysomatini Bickhardt \\
\hline Platysoma coarctatum J.E. LeConte \\
\hline Platysoma cylindricum (Paykull)** \\
\hline Platysoma deficiens (Casey)* \\
\hline Platysoma gracile J.E. LeConte \\
\hline Platysoma leconti Marseul* \\
\hline Tribe Histerini Gyllenhal \\
\hline Atholus bimaculatus (Linnaeus) \\
\hline Atholus perplexus (J.L. LeConte) \\
\hline Atholus sedecimstriatus (Say)** \\
\hline Hister abbreviatus Fabricius \\
\hline Hister curtatus LeConte \\
\hline
\end{tabular}




\begin{tabular}{l}
\hline Hister furtivus LeConte \\
\hline Margarinotus brunneus (Fabricius) \\
\hline Margarinotus cognatus (LeConte)* \\
\hline Margarinotus confusus Wenzel* \\
\hline Margarinotus egregius (Casey)* \\
\hline Margarinotus faedatus (LeConte) \\
\hline Margarinotus harrisii (Kirby)**
\end{tabular}

\begin{tabular}{l}
\hline Margarinotus hudsonicus (Casey) \\
\hline Margarinotus immunis (Erichson) \\
\hline Margarinotus interruptus (de Beauvois) \\
\hline Margarinotus lecontei Wenzel \\
\hline Margarinotus merdarius (Hoffmann)* \\
\hline Margarinotus stygicus (J.E. LeConte) \\
\hline Psiloscelis planipes (LeConte) \\
\hline
\end{tabular}

Notes: *New to province, ${ }^{* *}$ New to Maritime provinces.

\section{Species Accounts}

All records are species newly recorded for New Brunswick, Canada. Species followed by ${ }^{* *}$ are newly recorded from the Maritime provinces of Canada.

The classification of the Histeridae follows Bouchard et al. (2011).

\section{Histeridae Gyllenhal, 1808}

Subfamily Abraeinae MacLeay, 1819

Tribe Acritini Wenzel, 1944

\section{Acritus exiguus (Erichson, 1834)**}

http://species-id.net/wiki/Acritus_exiguus

Map 1

Material examined. New Brunswick, York Co., $15 \mathrm{~km} \mathrm{~W}$ of Tracy off Rt. 645, $45.6848^{\circ} \mathrm{N}, 66.8821^{\circ} \mathrm{W}, 16-30 . V I .2010$, R. Webster \& C. MacKay, old red pine forest, Lindgren funnel trap (1, RWC).

Collection and habitat data. This species occurs under bark of deciduous trees (Bousquet and Laplante 2006). The only specimen from New Brunswick was collected in a Lindgren funnel trap deployed in an old red pine (Pinus resinosa Ait.) forest. The adult was captured during June.

Distribution in Canada and Alaska. ON, QC, NB (Bousquet and Laplante 2006).

\section{Subfamily Saprininae Blanchard, 1845}

\section{Euspilotus rossi (Wenzel, 1939)**}

http://species-id.net/wiki/Euspilotus_rossi

Map 2

Material examined. New Brunswick, Queens Co., Rees near Grand Lake, $46.0016^{\circ} \mathrm{N}$, $65.9466^{\circ} \mathrm{W}, 29 . V .2007$, S. Makepeace \& R. Webster, in barred owl nest in an artificial nest box (2, CNC, RWC). 
Collection and habitat data. This species was reported from flicker (Colaptes auratus L.) nests by Kovarik and Caterino (2001). The specimens from New Brunswick were found in nest material of a barred owl nest with chicks. Euspilotus rossi was found in only one of 23 barred owl nests sampled (Webster and Makepeace, unpublished data), suggesting that this is not the usual habitat for this species. The two adults were collected in late May.

Distribution in Canada and Alaska. ON, QC, NB (Bousquet and Laplante 2006). Only a few specimens of this rare species are known from Canada (Bousquet and Laplante 2006).

\section{Gnathoncus barbatus Bousquet \& Laplante, 1999}

http://species-id.net/wiki/Gnathoncus_barbatus

Map 3

Material examined. New Brunswick, Carleton Co., Benton, $45.9961^{\circ} \mathrm{N}$, $67.5864^{\circ} \mathrm{W}, 24 . \mathrm{V} .2007$, Makepeace \& R. Webster, in barred owl nest in natural tree cavity (1, RWC). Queens Co., Pleasant Villa, $45.7023^{\circ} \mathrm{N}, 66.1732^{\circ} \mathrm{W}$, 15.VI.2007, S. Makepeace \& R. Webster, in barred owl nest in natural tree cavity (4, RWC, NBM); McAlpines near Upper Hampstead Rd., $45.7250^{\circ} \mathrm{N}, 66.1200^{\circ} \mathrm{W}$, 3.VI.2007, S. Makepeace \& R. Webster, in barred owl nest in natural tree cavity (4, RWC, NBM); Rees, near Grand Lake, $46.0016^{\circ} \mathrm{N}, 65.9466^{\circ} \mathrm{W}, 29 . \mathrm{V} .2007$, S. Makepeace \& R. Webster, in nest contents of barred owl in an artificial nest box (8, NBM). Sunbury Co., Noonan, $45.9923^{\circ}$ N, $66.4099^{\circ}$ W, 2.VI.2007, S. Makepeace $\&$ R. Webster, in barred owl from tree hole $7 \mathrm{~m}$ high in red maple, damp organic material with small bones (1, NBM); Acadia Research Forest, $45.9866^{\circ} \mathrm{N}$, 66.3841 ${ }^{\circ} \mathrm{W}, 2-9 . V I .2009$, R. Webster \& M.-A. Giguère, mature (100 year-old) red spruce forest with scattered red maple and balsam fir, Lindgren funnel trap (1, AFC). Westmorland Co., Sackville near Ogden Mill, 45.9216 $\mathrm{N}, 64.3893^{\circ} \mathrm{W}$, 12.V.2006, S. Makepeace \& R. Webster, in great horned owl nest (2, RWC, NBM). York Co., Charters Settlement, $45.8428^{\circ} \mathrm{N}, 66.7278^{\circ} \mathrm{W}$, in decayed mushrooms, 16.IX.2004, R. P. Webster (1, RWC); Keswick Ridge, $46.0040^{\circ} \mathrm{N}, 66.8776^{\circ} \mathrm{W}$, 23.V.2006, S. Makepeace \& R. Webster, in barred owl nest in natural tree cavity (2, RWC, NBM); Pokiok Settlement (String Bog), $45.9101^{\circ} \mathrm{N}, 67.1235^{\circ} \mathrm{W}$, 26.VI.2007, S. Makepeace \& R. Webster, in barred owl nest in natural tree cavity (1, RWC); Marysville, $45.9750^{\circ} \mathrm{N}, 66.5700^{\circ} \mathrm{W}, 22 . V I .2007$, S. Makepeace \& R. Webster, in barred owl nest, with dry organic material and remains of squirrel, birds, and insect parts (4, RWC, NBM).

Collection and habitat data. Little information was previously known about the habitat and biology of this species. Bousquet and Laplante (2006) reported one specimen from porcupine (Erethizon dorsatum (L.)) dung piled in a cavity at the base of an old sugar maple (Acer saccharum Marsh.). Most specimens from New Brunswick were collected from nest material of barred owl nests (most with chicks) in natural cavities in trees or in artificial nest boxes. Others were collected from a great horned owl (Bubo 
virginianus Gmelin) nest, decaying mushrooms, and a Lindgren funnel trap. This species is probably associated with birds and possibly mammals that nest in tree cavities. The nest contents of the barred owls and great horned owl contained decaying animal remains, and often many Diptera larvae were present on which the predaceous histerid adults and larvae were probably feeding. Adults were collected during May, June, and September.

Distribution in Canada and Alaska. BC, AB, ON, QC, NB, NS (Bousquet and Laplante 2006).

\section{Gnathoncus communis (Marseul, 1862)}

http://species-id.net/wiki/Gnathoncus_communis

Map 4

Material examined. New Brunswick, Kings Co., near Quarries, $45.6005^{\circ} \mathrm{N}$, $66.0500^{\circ} \mathrm{W}, 25 . \mathrm{IX} .2005$, S. Makepeace \& R. Webster, in barred owl nest in nest box on red maple, dry litter (2, RWC). Queens Co., Elm Hill, $45.7140^{\circ} \mathrm{N}$, $66.1315^{\circ} \mathrm{W}, 27 . \mathrm{VI} .2007, \mathrm{~S}$. Makepeace \& R. Webster, in barred owl nest in tree hole in red oak, damp (urine smell) organic material with feathers, fur and small bones (2, RWC).

Collection and habitat data. This species was collected from nest material from barred owl nests in natural cavities in trees or artificial nest boxes. Bousquet and Laplante (2006) reported this species as occurring in similar habitats. Adults were collected during June and September.

Distribution in Canada and Alaska. BC, AB, MB, ON, QC, NB, NS (Bousquet and Laplante 2006). This species is possibly adventive in North America (Bousquet and Laplante 2006).

Hypocaccus fitchi (Marseul, 1862)**

http://species-id.net/wiki/Hypocaccus_fitchi

Map 5

Material examined. New Brunswick, Queens Co., Bayard, at Nerepis River, $45.4473^{\circ} \mathrm{N}, 66.3318^{\circ} \mathrm{W}, 24 . \mathrm{V} .2009$, R. P. Webster, river margin, on sand bar in debris on sand (2, RWC).

Collection and habitat data. A few specimens from Quebec were found on sandy beaches along rivers (Bousquet and Laplante 2006). The New Brunswick specimens were found in debris resting on sand on a sand bar along a small river during late May.

Distribution in Canada and Alaska. ON, QC, NB (Bousquet and Laplante 2006). 


\section{Subfamily Dendrophilinae Reitter, 1909 \\ Tribe Dendrophilini Reitter, 1909}

\section{Dendrophilus kiteleyi Bousquet \& Laplante, 1999** \\ http://species-id.net/wiki/Dendrophilus_kiteleyi \\ Map 6}

Material examined. New Brunswick, Kings Co., near Quarries, $45.6005^{\circ} \mathrm{N}, 66.0500^{\circ} \mathrm{W}$, 25.IX.2005, S. Makepeace \& R. Webster, in barred owl nest in nest box on red maple, dry litter (1, RWC). Queens Co., Central Hampstead, $45.6575^{\circ} \mathrm{N}, 66.1412^{\circ} \mathrm{W}$, 13.VII.2006, S. Makepeace \& R. Webster, hardwood ridge, in nest of barred owl in tree hole (3, RWC, NBM); Elm Hill, 45.7140N, 66.1315W, 27.VI.2007, S. Makepeace \& $\mathrm{R}$. Webster, in barred owl nest in tree hole in red oak, damp (urine smell) organic material with feathers, fur and small bones (1, RWC); Pleasant Villa, $45.7023^{\circ} \mathrm{N}, 66.1732^{\circ} \mathrm{W}$, 15.VI.2007, S. Makepeace \& R. Webster, in barred owl nest in natural tree cavity (1, RWC); McAlpines near Upper Hampstead Rd., 45.7250 N, 66.1200W, 3.VI.2007, S. Makepeace \& R. Webster, in barred owl nest in natural tree cavity (4, RWC, NBM); Rees near Grand Lake, $46.0016^{\circ} \mathrm{N}, 65.9466^{\circ} \mathrm{W}, 29 . V .2007$, S. Makepeace \& R. Webster, in nest contents of barred owl in artificial nest box (1, RWC). York Co., Marysville, $45.9750^{\circ} \mathrm{N}, 66.5700^{\circ} \mathrm{W}, 22$. VI.2007, S. Makepeace \& R. Webster, in barred owl nest, with dry organic material and remains of squirrel, birds, and insect parts (1, RWC).

Collection and habitat data. Most specimens of $D$. kiteleyi were found in tree cavities in deciduous trees (Bousquet and Laplante 2006). All specimens from New Brunswick were collected from nest material from barred owl nests (most with chicks) in natural cavities in trees or in artificial nest boxes. Adults were collected during late May, June, July, and September.

Distribution in Canada and Alaska. AB, MB, ON, QC, NB (Bousquet and Laplante 2006).

\section{Dendrophilus punctatus (Herbst, 1792)}

http://species-id.net/wiki/Dendrophilus_punctatus

Map 7

Material examined. New Brunswick, Queens Co., Elm Hill, $45.7140^{\circ} \mathrm{N}, 66.1315^{\circ} \mathrm{W}$, 27.VI.2007, S. Makepeace \& R. Webster, in barred owl nest with chicks in a natural cavity in a red oak (1, RWC).

Collection and habitat data. In Europe, this species was frequently found in bird nests, granaries, and mills (Hinton 1945). In Canada, most records of this species were from tree cavities in deciduous trees (Bousquet and Laplante 2006). The specimen from New Brunswick was taken from the nest material of a barred owl in a tree cavity in a red oak (Quercus rubra L.) during late June. 


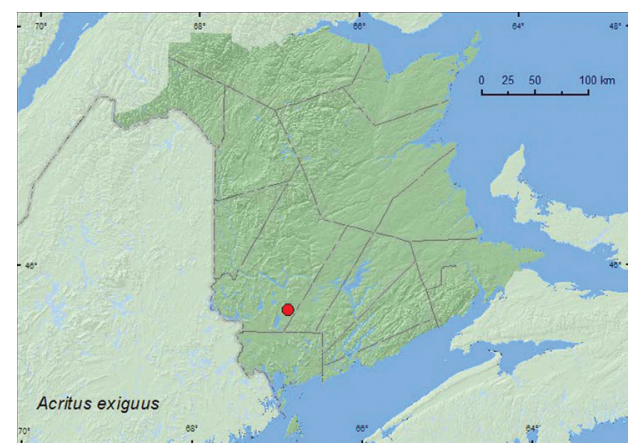

Map I. Collection localities in New Brunswick, Canada of Acritus exiguus.

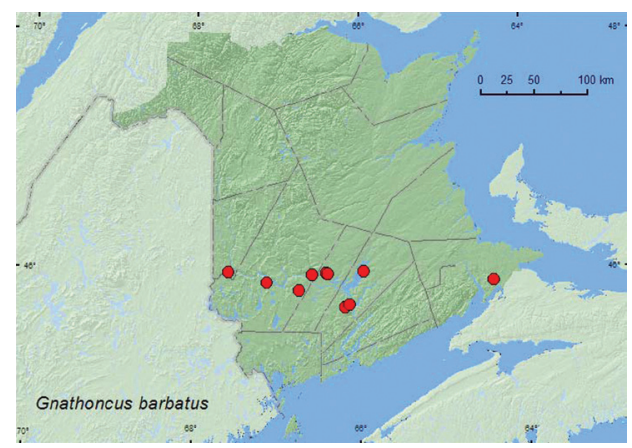

Map 3. Collection localities in New Brunswick, Canada of Gnathoncus barbatus.

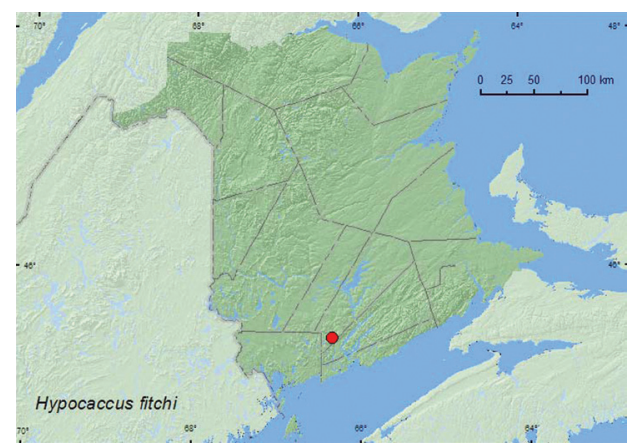

Map 5. Collection localities in New Brunswick, Canada of Hypocaccus fitchi.

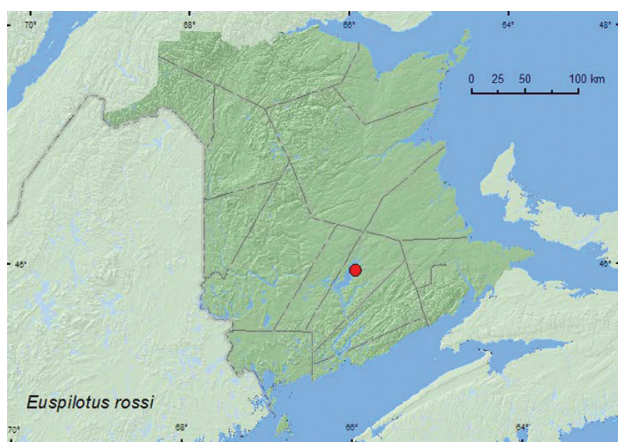

Map 2. Collection localities in New Brunswick, Canada of Euspilotus rossi.

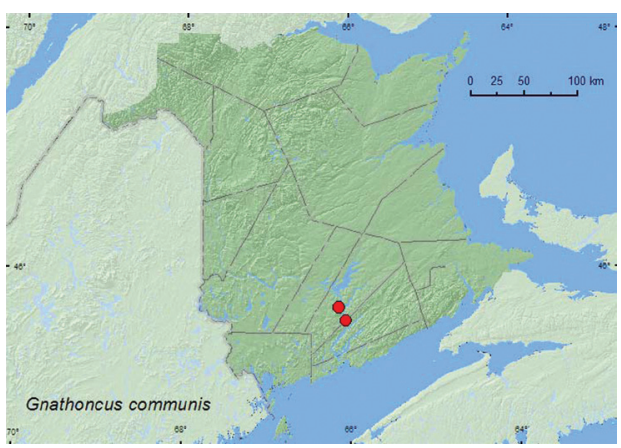

Map 4. Collection localities in New Brunswick, Canada of Gnathoncus communis.

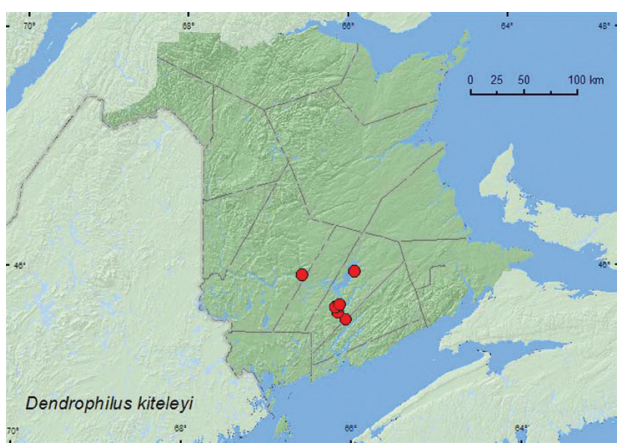

Map 6. Collection localities in New Brunswick, Canada of Dendrophilus kiteleyi.

Distribution in Canada and Alaska. MB, ON, QC, NB, NS (Bousquet and Laplante 2006). This adventive species is now widespread in North America (Bousquet and Laplante 2006). 
Subfamily Histerinae Gyllenhal, 1808

Tribe Platysomatini Bickhardt, 1914

Platysoma cylindricum (Paykull, 1811)**

http://species-id.net/wiki/Platysoma_cylindricum

Map 8

Material examined. New Brunswick, York Co., Fredericton, 28.VI.1929, L. J. Simpson, in tunnel of Ips pini (in pine) (1, AFC).

Collection and habitat data. This species occurs under bark of dead pines (Bousquet and Laplante 2006). The New Brunswick specimen was found in a tunnel of I $p$ s pini (Say), presumably in a dead pine. The adult was captured during late June.

Distribution in Canada and Alaska. ON, QC, NB (Bousquet and Laplante 2006).

Platysoma deficiens (Casey, 1924)

http://species-id.net/wiki/Platysoma_deficiens

Map 9

Material examined. New Brunswick, Charlotte Co., Oak Bay, 6.VII.1928, L. J. Simpson, from Ips pini tunnels (1, AFC). Sunbury Co., Acadia Research Forest, $45.9866^{\circ} \mathrm{N}, 66.3841^{\circ} \mathrm{W}, 18-24 . V I .2009,24-30 . V I .2009,18-31 . V I I I .2009$, R. Webster \& M.-A. Giguère, mature (110 year-old) red spruce forest with scattered red maple and balsam fir, Lindgren funnel traps (3, AFC, RWC). York Co., Taymouth, 29.VI.1929 (no collector given) (1, AFC); Fredericton, 22.VI.1929, L. J. Simpson, (1, AFC); $15 \mathrm{~km} \mathrm{~W}$ of Tracy off Rt. $645,45.6848^{\circ} \mathrm{N}, 66.8821^{\circ} \mathrm{W}, 21-28$. VI.2009, 7-14.VII.2009, 4-11.VIII.2009, 11-18.VIII.2009, R. Webster \& M.-A. Giguère, old red pine forest, Lindgren funnel traps (4, AFC, RWC); same locality data but 6.VI.2009, R. Webster \& M.-A. Giguère, old red pine forest, under bark scales of recently fallen red pine (4, RWC); $14 \mathrm{~km} \mathrm{WSW} \mathrm{of} \mathrm{Tracy,} \mathrm{S} \mathrm{of} \mathrm{Rt.} \mathrm{645,}$ $45.6741^{\circ} \mathrm{N}, 66.8661^{\circ} \mathrm{W}, 10-26 . V .2010$, R. Webster \& C. MacKay, old mixed forest with red and white spruce, red and white pine, balsam fir, eastern white cedar, red maple, and Populus sp., Lindgren funnel traps (6, AFC).

Collection and habitat data. This species is found under bark of dead pines ( $P i$ nus spp.), spruce (Picea spp.), and larches (Larix sp.) (Bousquet and Laplante 2006). In New Brunswick, specimens were collected from Ips pini tunnels, from under bark scales of a recently fallen red pine, and in Lindgren funnel traps in a variety of forest types with conifers. Adults were collected during May, June, July, and August.

Distribution in Canada and Alaska. AB, SK, MB, ON, QC, NB, NS (Bousquet and Laplante 2006). 


\section{Platysoma leconti Marseul, 1853}

http://species-id.net/wiki/Platysoma_leconti

Map 10

Material examined. New Brunswick, Carleton Co., Meduxnekeag Valley Nature Preserve, $46.1888^{\circ} \mathrm{N}, 67.6762^{\circ} \mathrm{W}, 20 . \mathrm{V} .2005$, R. P. Webster (1, RWC). Northumberland Co., $12.0 \mathrm{~km}$ SSE of Upper Napan near Goodfellow Brook, 46.8943N, $65.3810^{\circ} \mathrm{W}, 23 . V .2007$, R. P. Webster, recent clear-cut, under bark of spruce log (1, NBM). Queens Co., Cranberry Lake P.N.A. (Protected Natural Area), $46.1125^{\circ} \mathrm{N}$, 65.6075 ${ }^{\circ}$ W, 25.VI.2009, R. Webster \& M.-A. Giguère, mature red oak forest, on dead red oak trunk (1, AFC); same locality data and forest type, 13-25.V.2011, 29.VI-7.VII.2011, M. Roy \& V. Webster, Lindgren funnel traps (2, NBM). Restigouche Co., Jacquet River Gorge P.N.A., 47.8779 N, 66.0013² W, 13.VI.2009, R. P. Webster, mixed forest, under bark of birch with fermented sap (2, RWC). Sunbury Co., Portobello Creek N.W.A., $45.8992^{\circ}$ N, $66.4248^{\circ}$ W, 5.VI.2004, R. P. Webster (1, RWC); Lakeville Corner, $45.9007^{\circ} \mathrm{N}, 66.2423^{\circ} \mathrm{W}, 27$. VIII.2006, R. P. Webster, silver maple swamp, among polypore fungi on poplar log (1, NBM). York Co., near Magaguadavic Lake, $45.7283^{\circ} \mathrm{N}, 67.1818^{\circ} \mathrm{W}, 24 . I V .2004$, D. Sabine \& R. Webster (3, NBM, RWC); Charters Settlement, $45.8340^{\circ} \mathrm{N}, 66.7450^{\circ} \mathrm{W}, 14$. V.2004, R. P. Webster (1, RWC); $15 \mathrm{~km} \mathrm{~W}$ of Tracy off Rt. $645,45.6848^{\circ} \mathrm{N}, 66.8821^{\circ} \mathrm{W}, 4-11 . V I I I .2009, \mathrm{R}$. Webster \& M.-A. Giguère, old red pine forest, Lindgren funnel trap (1, AFC).

Collection and habitat data. Platysoma lecont $i$ is found under bark of a variety of dead deciduous tree species (maples (Acer spp.), oaks (Quercus spp.), elm (Ulmus spp.), poplars (Populus sp.), ashes (Fraxinus spp.)) and pines (Bousquet and Laplante 2006). In New Brunswick, this species was found under bark of a red oak, under bark with fermented sap of a dead standing birch (Betula sp.), and among polypore fungi on a poplar log. Adults were also caught in Lindgren funnel traps. Adults were captured during April, May, June, and August.

Distribution in Canada and Alaska. NT, BC, AB, SK, MB, ON, QC, NB, NS (Bousquet and Laplante 2006).

\section{Tribe Histerini Gyllenhal, 1808}

Atholus perplexus (J. L. LeConte, 1863)

http://species-id.net/wiki/Atholus_perplexus

Map 11

Material examined. New Brunswick, York Co., Charters Settlement, $45.8456^{\circ} \mathrm{N}$, $66.7267^{\circ} \mathrm{W}, 10 . \mathrm{VI} .2010$, R. P. Webster, beaver dam among sticks and debris on top of dam (2, RWC).

Collection and habitat data. Atholus perplexus has been collected from North American beaver (Castor canadensis Kuhl) lodges, muskrat (Ondatra zibethicus (L.)) nests, and in manure (Bousquet and Laplante 2006). The specimens from New Brunswick were 
collected among sticks and debris on top of a beaver dam. Beaver dung was present in the material on the top of the dam. The two adults were collected during June.

Distribution in Canada and Alaska. SK, MB, ON, QC, NB, PE, NS (Bousquet and Laplante 2006).

Atholus sedecimstriatus (Say, 1825)**

http://species-id.net/wiki/Atholus_sedecimstriatus

Map 12

Material examined. New Brunswick, York Co., Charters Settlement, $45.8340^{\circ} \mathrm{N}$, $66.7450^{\circ} \mathrm{W}, 20$. VIII.2006, R. Webster, well decayed gilled and boletus mushrooms placed in an opening of 20 year-old regenerating mixed forest (1, RWC).

Collection and habitat data. This species occurs in compost, dung, and carrion (Bousquet and Laplante 2006). The specimen from New Brunswick was found in welldecayed mushrooms during August.

Distribution in Canada and Alaska. ON, QC, NB (Bousquet and Laplante 2006).

\section{Margarinotus cognatus (J. E. LeConte, 1844)}

http://species-id.net/wiki/Margarinotus_cognatus

Map 13

Material examined. New Brunswick, Gloucester Co., 3 Vinot Rd. (Duguayville), 17.VI.1941, E. Dugway, 41-L68 (FIS) (1, AFC). York Co., Charters Settlement, $45.8340^{\circ} \mathrm{N}, 66.7450^{\circ} \mathrm{W}$, 8.VIII.2006, 14.VIII.2006, 20.VIII.2006, R. P. Webster, baited with well-decayed gilled and boletus mushrooms (7, RWC); $15 \mathrm{~km} \mathrm{~W}$ of Tracy off Rt. 645, $45.6848^{\circ} \mathrm{N}, 66.8821^{\circ} \mathrm{W}, 28 . V I-7 . V I I .2009$, R. Webster \& M.-A. Giguère, old red pine forest, Lindgren funnel trap (1, AFC).

Collection and habitat data. Most adults from New Brunswick were collected from well-decayed gilled and boletus mushrooms that had been placed in an opening in a 20 -year-old regenerating mixed forest. One individual was caught in a Lindgren funnel trap deployed in an old red pine forest. Adults were collected during June, July, and August. Little was previously known about the biology of this species (Bousquet and Laplante 2006).

Distribution in Canada and Alaska. ON, QC, NB, NS (Bousquet and Laplante 2006).

\section{Margarinotus confusus Wenzel, 1944}

http://species-id.net/wiki/Margarinotus_confusus

Map 14

Material examined. New Brunswick, Carleton Co., Meduxnekeag Valley Nature Preserve, $46.1964^{\circ} \mathrm{N}, 67.6340^{\circ} \mathrm{W}, 31 . \mathrm{V} .2005$, M.-A. Giguère \& R. Webster, old 


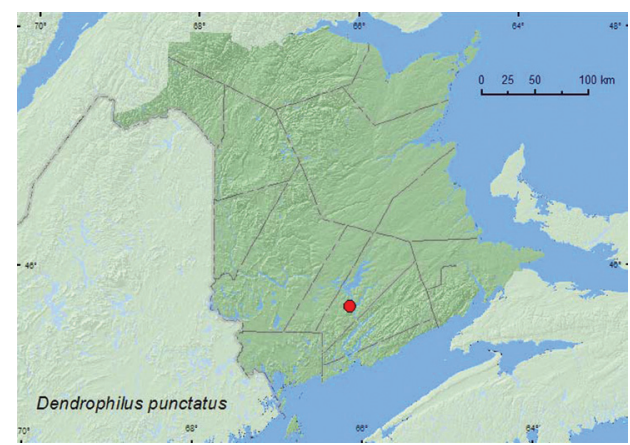

Map 7. Collection localities in New Brunswick, Canada of Dendrophilus punctatus.

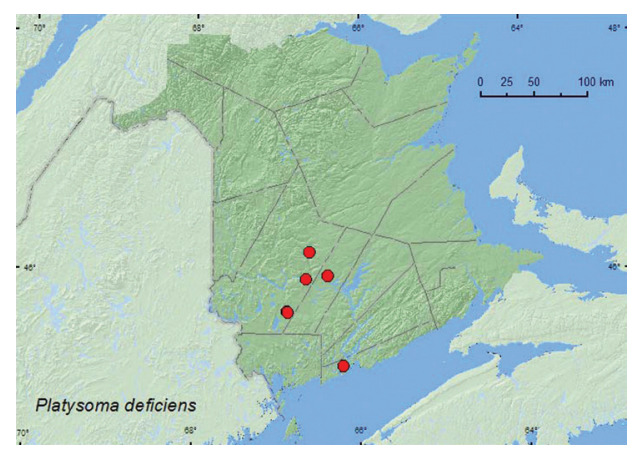

Map 9. Collection localities in New Brunswick, Canada of Platysoma deficiens.

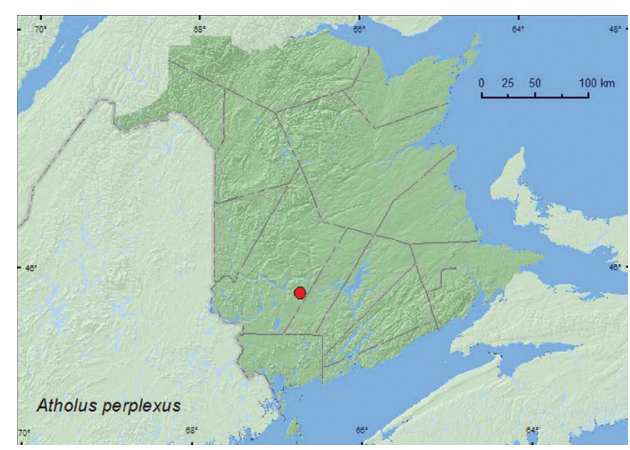

Map I I. Collection localities in New Brunswick, Canada of Atholus perplexus.

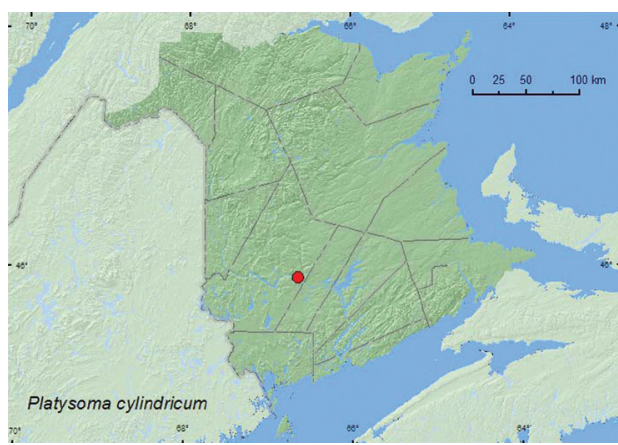

Map 8. Collection localities in New Brunswick, Canada of Platysoma cylindricum.

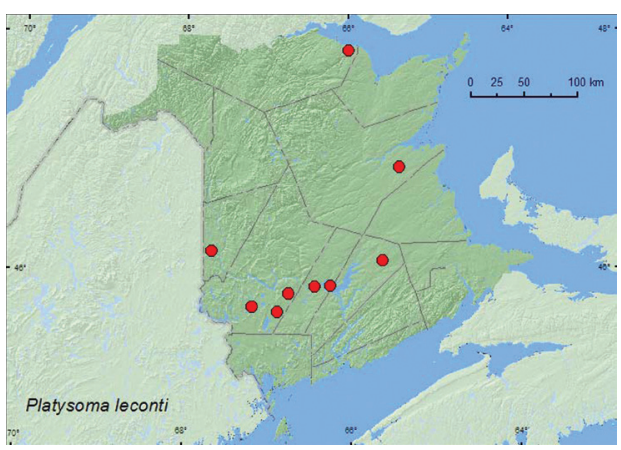

Map 10. Collection localities in New Brunswick, Canada of Platysoma leconti.

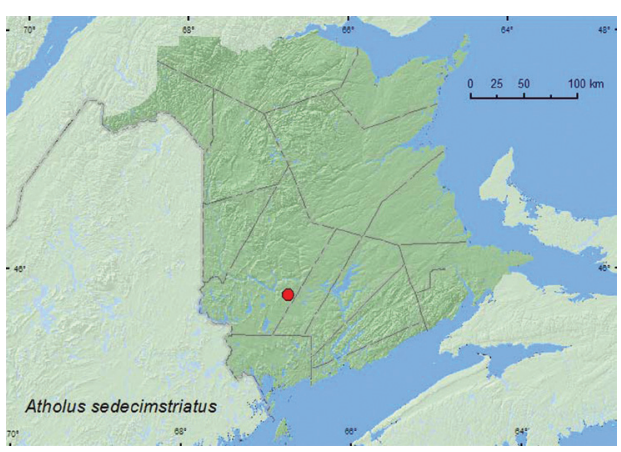

Map I2. Collection localities in New Brunswick, Canada of Atholus sedecimstriatus.

mixed forest, in moist leaf litter at the margin of a vernal pond (1, RWC); Lower Woodstock, $46.1192^{\circ} \mathrm{N}, 67.5795^{\circ} \mathrm{W}, 7 . V .2008$, R. P. Webster, pasture, entrance to fox den (3, RWC). York Co., Charters Settlement, $45.8430^{\circ} \mathrm{N}, 66.7275^{\circ} \mathrm{W}, 5$. V.2006, R. P. Webster, in porcupine dung at the entrance of a porcupine den (1, RWC). 
Collection and habitat data. This species has been collected in woodchuck (Marmota monax (L.)) burrows and carrion (Bousquet and Laplante 2006). In New Brunswick, adults were collected from the entrance of a fox (Vulpes sp.) den, the entrance of a porcupine den in dung, and in moist leaf litter on the margin of a vernal pond. Adults were collected during May.

Distribution in Canada and Alaska. ON, QC, NB, NS (Bousquet and Laplante 2006).

\section{Margarinotus egregius (Casey, 1916)}

http://species-id.net/wiki/Margarinotus_egregius

Map 15

Material examined. New Brunswick, Carleton Co., Lower Woodstock, $46.1192^{\circ} \mathrm{N}$, $67.5795^{\circ} \mathrm{W}, 7 . V .2008$, R. P. Webster, pasture, entrance to fox den (1, RWC).

Collection and habitat data. This species is commonly found in woodchuck burrows early in the spring and also in various decaying organic material such as carrion, dung, and decaying mushrooms (Bousquet and Laplante 2006). The specimen from New Brunswick was collected from the entrance of a fox den in May.

Distribution in Canada and Alaska. MB, ON, QC, NB, NS (Bousquet and Laplante 2006).

\section{Margarinotus harrisii (Kirby, 1837)**}

http://species-id.net/wiki/Margarinotus_harrisii

Map 16

Material examined. New Brunswick, Charlotte Co., 3.0 km NW of Pomeroy Ridge, $45.3095^{\circ} \mathrm{N}, 67.4343^{\circ} \mathrm{W}, 16 . \mathrm{VI} .2008$, R. P. Webster, old growth eastern white cedar swamp, in moss and leaf litter near small vernal pool (1, RWC). Sunbury Co., Acadia Research Forest, $45.9866^{\circ} \mathrm{N}, 66.3841^{\circ} \mathrm{W}, 2-9 . V I .2009$, R. Webster \& M.-A. Giguère, mature (110 year-old) red spruce forest with scattered red maple and balsam fir, Lindgren funnel trap (1, RWC).

Collection and habitat data. One of the New Brunswick specimens was collected in moss and leaf litter near a vernal pond, the other from a Lindgren funnel trap. In Indiana (USA), the species was usually found in cow dung and was frequent under "chunks" on the beach of Lake Michigan (Blatchley 1910). Adults were collected during June in New Brunswick.

Distribution in Canada and Alaska. BC, AB, SK, MB, ON, QC, NB (Bousquet and Laplante 2006). 
Margarinotus merdarius (Hoffman, 1803)

http://species-id.net/wiki/Margarinotus_merdarius

Map 17

Material examined. New Brunswick, Kings Co., ca. $2 \mathrm{~km}$ WSW of Browns Flat, $45.4667^{\circ} \mathrm{N}, 66.1668^{\circ} \mathrm{W}, 8$. VII.2009, S. Makepeace \& R. Webster, in barred owl nest box, moist organic debris and sawdust with owl pellets, small bones, feathers, with urine smell (1, RWC). Queens Co., Central Hampstead, $45.6575^{\circ} \mathrm{N}$, $66.1412^{\circ} \mathrm{W}, 13 . \mathrm{VII} .2006$, S. Makepeace \& R. Webster, hardwood ridge, in barred owl nest in tree hole (1, RWC); Elm Hill, $45.7140^{\circ} \mathrm{N}, 66.1315^{\circ} \mathrm{W}, 27 . \mathrm{VI} .2007$, S. Makepeace \& R. Webster, in barred owl nest in tree hole in red oak, damp (urine smell) organic material with feathers, fur and small bones (1, RWC); Cumberland Bay, $46.0000^{\circ} \mathrm{N}, 65.9333^{\circ} \mathrm{W}, 28 . V I .2009$, Makepeace \& R. Webster, in barred owl nest, moist leaves and debris with owl pellets, small bones, with urine smell (1, RWC); ca. $1.5 \mathrm{~km} \mathrm{NW}$ of McAlpines, $45.7333^{\circ} \mathrm{N}, 66.1333^{\circ} \mathrm{W}, 8 . \mathrm{VII} .2009$, S. Makepeace $\&$ R. Webster, in barred owl nest box, moist organic debris and sawdust with owl pellets, small bones, feathers, with urine smell (2, RWC). York Co., Marysville, $45.9750^{\circ} \mathrm{N}, 66.5700^{\circ} \mathrm{W}, 22 . V I .2007$, S. Makepeace \& R. Webster, nest box contents of barred owl, with dry organic material and remains of squirrel, birds, and insect parts (1, NBM).

Collection and habitat data. In Europe, this species occurs in dung, fungi, compost, and decaying vegetables and in bird nests and henhouses (Vienna 1980). All specimens of this adventive species from New Brunswick were collected from nest material from barred owl nests (most with chicks) in natural cavities in trees or in artificial nest boxes. Adults were captured during June and July.

Distribution in Canada and Alaska. BC, AB, MB, ON, QC, NB, NS (Bousquet and Laplante 2006).

Margarinotus stygicus (J. E. LeConte, 1845)

http://species-id.net/wiki/Margarinotus_stygicus

Map 18

Material examined. New Brunswick, York Co., Charters Settlement, $45.8395^{\circ} \mathrm{N}$, $66.7391^{\circ} \mathrm{W}, 19$. VI.2004, R. P. Webster, pitfall trap baited with dog dung (1, RWC).

Collection and habitat data. Relatively little is known about the habitat requirements of this species. The scant habitat data available suggest that the species is probably associated with mammal nests. Adults have been collected by sifting around a deserted mouse nest (Blatchley 1910) and from a fox burrow (Bousquet and Laplante 2006). The specimen from New Brunswick was captured during June in a pitfall trap baited with dog dung.

Distribution in Canada and Alaska. MB, ON, NB, NS (Bousquet and Laplante 2006). Majka (2008) considered this species to be disjunct in Nova Scotia due to a lack of records from Quebec and other regions of Atlantic Canada. 


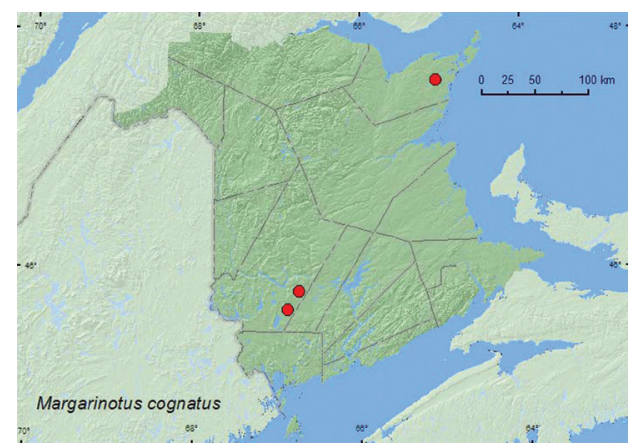

Map 13. Collection localities in New Brunswick, Canada of Margarinotus cognatus.

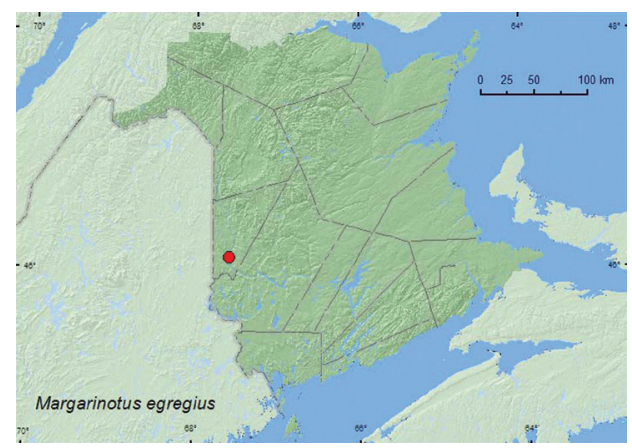

Map 15. Collection localities in New Brunswick, Canada of Margarinotus egregius.

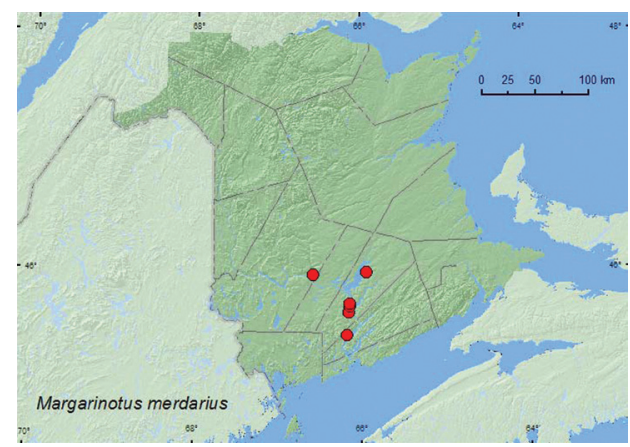

Map 17. Collection localities in New Brunswick, Canada of Margarinotus merdarius.

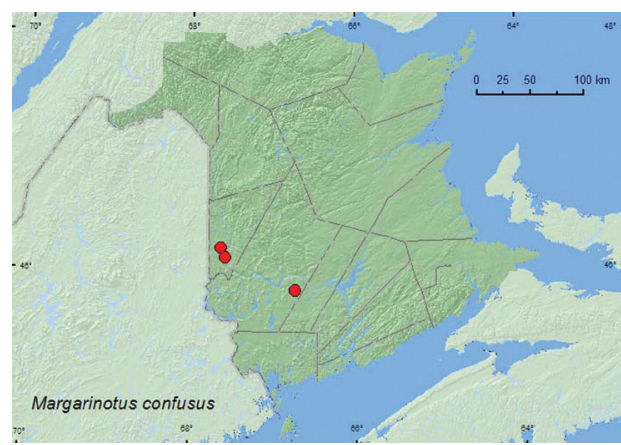

Map 14. Collection localities in New Brunswick, Canada of Margarinotus confusus.

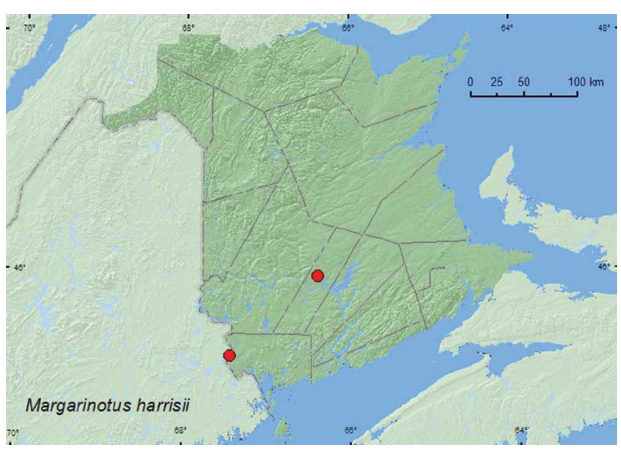

Map 16. Collection localities in New Brunswick, Canada of Margarinotus harrisii.

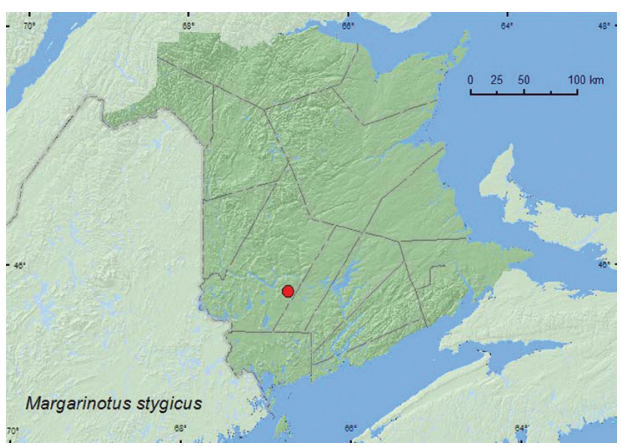

Map I 8. Collection localities in New Brunswick, Canada of Margarinotus stygicus.

\section{Acknowledgments}

We thank Caroline Simpson for editing this manuscript. Yves Bousquet (Agriculture and Agri-Food Canada (CNC), Ottawa) is thanked for determining the specimens and revising the manuscript and anonymous reviewer is thanked for useful comments. 
We thank Nichole Brawn, Katie Burgess, Marie-Andrée Giguère, Nancy Harn, Cory Hughes, Ervin Kovacs, Colin MacKay, Wayne MacKay, Jessica Price, Michelle Roy, and Vincent Webster for technical assistance and collecting specimens. We thank Natural Resources Canada Canadian Forest Service; the Canadian Food Inspection Agency; and USDA APHIS for funding the Lindgren funnel trapping component of this study. We thank the Canadian Wildlife Service for funding insect surveys at the Portobello Creek National Wildlife Area, and the New Brunswick Environmental Trust Fund and New Brunswick Wildlife Trust Fund for funding various insect surveys over the past 7 years. The Meduxnekeag River Association is thanked for permission to sample beetles at the Meduxnekeag Valley Nature Preserve (which includes the Bell Forest). The New Brunswick Department of Natural Resources (Fish and Wildlife Branch) is thanked for issuing permits for sampling in the Protected Natural Areas and logistical support. Survey work in the Jacquet River Gorge Protected Natural Area was organized through the New Brunswick Museum with external funding from the New Brunswick Environmental Trust Fund, Salamander Foundation, and the New Brunswick Wildlife Trust Fund.

\section{References}

Blatchley WS (1910) An illustrated descriptive catalogue of the Coleoptera or beetles (exclusive of the Rhynchophora) known to occur in Indiana. The Nature Publishing Co., Indianapolis, 1358 pp. doi: 10.5962/bhl.title.56580

Bouchard P, Bousquet Y, Davies AE, Alonso-Zarazaga MA, Lawrence JF, Lyal CHC, Newton AF, Reid CAM, Schmitt M, Ślipiński SA, Smith ABT (2011) Family-group names in Coleoptera (Insecta). ZooKeys 88: 1-972. doi: 10.3897/zookeys.88.807

Bousquet Y, Laplante S (2006) Coleoptera Histeridae: The Insects and Arachnids of Canada, part 24. NRC Research Press, Ottawa, 485 pp.

Hinton HE (1945) The Histeridae associated with stored products. Bulletin of Entomological Research 35: 309-340.

Kovarik PW, Caterino MS (2001) Family 15, Histeridae Gyllenhal, 1808. [pp. 212-227] In: Arnett RH Jr, Thomas MC (Eds) American Beetles, Volume 1. Archostemata, Myxophaga, Adephaga, Polyphaga: Staphyliniformia. CRC Press, Boca Raton, Florida, xv +443 pp.

Majka CG (2008) Contributions to the knowledge of Atlantic Canadian Histeridae (Coleoptera). ZooKeys 2: 189-202. doi: 10.3897/zookeys.2.3

Vienna P (1980) Coleoptera Histeridae. Fauna d'Italia, vol. XVI. Calderini, Bologna, ix + 386 pp.

Webster RP, Klimaszewski J, Pelletier G, Savard K (2009) New Staphylinidae (Coleoptera) records with new collection data from New Brunswick, Canada. I. Aleocharinae. In: Majka CG, Klimaszewski J (Eds) Biodiversity, Biosystematics, and Ecology of Canadian Coleoptera II. ZooKeys 22: 171-248. doi: 10.3897/zookeys.22.152

Webster RP, Smetana A, Sweeney JD, DeMerchant I (in press) New Staphylinidae (Coleoptera) records with new collection data from New Brunswick and an addition to the fauna of Quebec: Staphylininae. In: Klimaszewski J, Anderson R (Eds) Biodiversity, Biosystematics and Ecology of Canadian Staphylinidae (Coleoptera) II. ZooKeys. 